\title{
SUPLEMENTASI MINERAL ESENSIAL DALAM RANSUM TERHADAP LITTER SIZE, BOBOT LAHIR DAN PERBANDINGAN ANAK JANTAN DAN BETINA PADA KELINCI (Oryctolagus cuniculus)
}

\section{(Supplementation of Essential Minerals on Feed to Litter Size, Weight of Birth, Male And Female Ratio on Litter Size of The Rabbit (Oryctolagus cuniculus))}

\author{
Dwi Purnama Putri ${ }^{1}$, Zulfikar Siregar ${ }^{2}$ dan Ristika Handarini ${ }^{3}$ \\ 1. Mahasiswa Program Studi Peternakan Fakultas Pertanian Universitas Sumatera Utara \\ 2. Staf Pengajar Program Studi Peternakan Fakultas Pertanian Universitas Sumatera Utara \\ 3. Staf Pengajar Program Studi Peternakan Fakultas Pertanian Universitas Djuanda, Bogor
}

\begin{abstract}
Ratio of male births more than female per litter size in rabbits results take a long time for breeding. Therefore, a research has been studied using essential which is aimed to increase the number of rabbit female on litter size. This research was conducted at livestock farmers group "Rehna Latersia", in the sub-distric of Berastagi during June to September 2012. This research was used 36 rabbits ( 27 doe and 9 buck). This research was used randomized block design with three block based on rabbit body weight. The three treatments were T0 (control, natural condition), T1 (acid feed, contains of essential minerals P $0,37 \%$ and $\mathrm{Cl} 0,5 \%$ on feed), and T2 (base feed, contains of essential minerals $\mathrm{Na} 0,5 \%$ and $\mathrm{Ca} 0,45 \%$ on feed). The three parameters were litter size, weight of birth and male and female ratio on litter size. The results indicated no significant different effect $(\mathrm{P}>0,05)$ on all of parameters is : litter size, weight of birth and male and female ratio on litter size. The conclusion showed that supplementation of essential minerals on feed not been able to increased the number of rabbit female on litter size.
\end{abstract}

Keywords: Rabbit, essential minerals, acid, base, male female ratio.

\begin{abstract}
ABSTRAK
Banyaknya kelahiran anak jantan dibanding betina dalam satu litter size kelinci mengakibatkan perkembangbiakan lebih lama, untuk itu telah dilakukan penelitian menggunakan mineral esensial yang bertujuan untuk meningkatkan jumlah anak betina dalam satu litter size. Penelitian dilakukan di Kelompok Tani Ternak "Rehna Latersia" kecamatan Berastagi pada Juni-September 2012. Penelitian ini menggunakan 36 ekor kelinci (27 ekor kelinci betina dan 9 ekor kelinci pejantan). rancangan acak kelompok terdiri atas tiga kelompok yang dibedakan berdasarkan bobot badan kelinci. Ada tiga perlakuan yaitu T0 sebagai pakan kontrol, T1 pakan bersifat asam (mengandung mineral $\mathrm{P} 0,37 \%$ dan $\mathrm{Cl}$ 0,5\%), dan $\mathrm{T} 2$ pakan bersifat basa (mengandung mineral $\mathrm{Na} 0,5 \%$ dan $\mathrm{Ca} 0,45 \%$ ). Parameter yang diamati adalah litter size, bobot lahir dan perbandingan anak jantan dan betina. Hasil penelitian menunjukkan bahwa perlakuan pakan baik yang bersifat asam maupun basa memberikan hasil yang tidak berbeda nyata $(\mathrm{P}>0,05)$, terhadap litter size, bobot lahir dan perbandingan anak jantan dan betina kelinci. Kesimpulan menunjukkan bahwa suplementasi mineral esensial yang dapat merubah kondisi asam dan basa pakan belum mampu meningkatkan jumlah anak betina per litter size.
\end{abstract}

Kata kunci : Kelinci, mineral esensial, asam, basa, anak betina, anak jantan

\section{PENDAHULUAN}

Program Swasembada Daging yang dicanangkan pemerintah ditahun 2014 perlu didukung, terutama oleh masyarakat Peternakan. Dukungan itu lebih baik lagi jika dilakukan bersamaan dengan pengembangan plasma nutfah pada hewan lokal. Baik pengembangan kualitas produksi maupun meningkatkan pupulasi. 
Indonesia memiliki beragam kekayaan alam dan selera konsumsi masyarakatnya yang beragam pula. Kelinci merupakan ternak alternatif yang mulai banyak digemari dibeberapa daerah. Misalnya di Jawa Tengah dan Jawa Timur. Sementara di Sumatera Utara sendiri potensi kelinci sebagai sumber protein masih belum dimanfaatkan secara optimal. Umumnya lebih banyak dilirik sebagai hewan kesayangan. Padahal, daging kelinci memiliki potensi yang sangat baik jika dibandingkan dengan daging ternak lain.

Jika dilihat dari segi nutrisi, daging kelinci banyak mengandung protein yang baik dengan kadar lemak yang rendah. Berdasarkan rasa, daging kelinci hampir sama dengan daging ayam. Oleh karena itu kelinci dapat diikut sertakan untuk mengatasi masalah kebutuhan protein di Indonesia. Sementara dari segi reproduksi, kelinci adalah mamalia yang memiliki siklus reproduksi cukup singkat, dengan kemampuan menghasilkan anak banyak dalam sakelahiran (politocus). Kemampuan politocus itu akan lebih baik lagi jika dikendalikan dengan meningkatkan jumlah anak betina disetiap kelahiran, sehingga perbanyakan dapat dilakukan lebih cepat.

Sejauh ini, berbagai metode telah dilakukan untuk mengubah perbandingan jenis kelamin anak pada ternak (Sumaryadi, 2011), akan tetapi cenderung membutuhkan peralatan yang sulit dan biaya yang cukup mahal. Selain itu memerlukan keahlian khusus, misalnya inseminasi menggunakan sperma sexing, super ovulasi, transfer embrio, penyesuaian masa estrus dan sebagainya. Teknologi-teknologi tersebut umumnya hanya dapat dilakukan oleh tenaga ahli terdidik, sehingga kurang memasyarakat, karena hanya dapat dilakukan oleh suatu skala usaha menengah keatas. Sementara, suplai sumber protein harus cepat dipenuhi untuk menunjang kelangsungan hidup masyarakat yang berkualitas.

Penggunaan mineral telah lama diaplikasikan oleh masyarakat Indonesia, yang tujuannya untuk meningkatkan produktifitas individu ternak dalam bentuk daging, telur dan susu. Lebih dari itu mineral yang tepat dapat mempengaruhi asam basa dalam tubuh yang juga akan mempengaruhi proses embrional khususnya pembentukan jenis kelamin anak.

Berdasarkan uraian diatas, penulis tertarik untuk melakukan penelitian lebih lanjut menggunakan mineral pembentuk asam-basa dalam alat reproduksi untuk meningkatkan anak betina dalam sekelahiran serta pengaruhnya terhadap jumlah anak dan bobot lahir pada kelinci lokal. 


\section{BAHAN DAN METODE}

\section{Lokasi dan Waktu Penelitian}

Penelitian ini dilaksanakan di Kelompok Tani Ternak "Rehna Latersia" yang berada di Gang Rukun Jl. Udara Kecamatan Berastagi Kabupaten Karo. Lokasi berada diketinggian 1368 meter diatas permukaan laut, dengan suhu harian rata-rata $17-25^{\circ} \mathrm{C}$. Penelitian dilaksanakan pada bulan Juni sampai September 2012. Sedangkan pembuatan pellet dilaksanakan di Compost Centre Universitas Sumatera Utara.

\section{Bahan dan Alat Penelitian}

Bahan yang digunakan adalah kelinci lokal terdiri atas betina 27 ekor dan jantan sebanyak 9 ekor dengan kisaran bobot badan 1-4,2 kg. Ransum dengan tiga treatment yaitu T0 (ransum kontrol, tanpa penambahan mineral asam dan basa), T1 (ransum yang ditambah dengan mineral $\mathrm{P}$ dan $\mathrm{Cl}$ ) dan $\mathrm{T} 2$ (ransum yang ditambah dengan mineral $\mathrm{Na}$ dan $\mathrm{Ca}$ ). Daun wortel dan daun kol. Air untuk minum dan Rodalon ${ }^{\circledR}$ sebagai desinfektan kandang.

Alat yang digunakan adalah mesin pencetak pellet. Kandang individu sebanyak 36 petak (tiap petak berukuran $80 \mathrm{~cm}$ x $80 \mathrm{~cm}$ x $70 \mathrm{~cm}, 27$ petak untuk kelinci betina dan 9 petak untuk kelinci jantan). Tempat pakan dan tempat minum, termometer, kertas $\mathrm{pH}$, timbangan digital kapasitas $5 \mathrm{~kg}$ dengan kepekaan 0,01 g, kamera digital dan pembersih kandang (sapu, sikat lantai dan ember).

Ransum disusun dari beberapa bahan dalam bentuk pellet, formula ransum yang digunakan untuk kelinci bunting dapat dilihat pada Tabel 1, dan kelinci laktasi pada Tabel 2.

Tabel 1. Formula ransum kelinci bunting

\begin{tabular}{lccc}
\hline \multicolumn{1}{c}{ Bahan pakan } & T0 (\%) & T1 (\%) & T2 (\%) \\
\hline Tepung jagung & 40 & 40 & 40 \\
Bungkil Inti Sawit & 15 & 15 & 15 \\
Bungkil kedelai & 15 & 15 & 15 \\
Dedak halus & 19 & 20 & 20 \\
Molasses & 10 & 9,13 & 9,05 \\
Garam & 0,5 & - & - \\
Mineral mix & 0,5 & - & - \\
$\mathrm{NH} 4 \mathrm{Cl}$ & - & 0,5 & - \\
$\left(\mathrm{NH}_{4}\right)_{3} \mathrm{PO}_{4}$ & - & 0,37 & - \\
$\mathrm{Na}_{2} \mathrm{CO}_{3}$ & - & - & 0,5 \\
$\mathrm{CaCO}_{3}$ & - & - & 0,45 \\
\hline
\end{tabular}


Tabel 2. Formula ransum kelinci laktasi

\begin{tabular}{lccc}
\hline \multicolumn{1}{c}{ Bahan pakan } & T0 (\%) & T1(\%) & T2(\%) \\
\hline Tepung jagung & 40 & 40 & 40 \\
Bungkil Inti Sawit & 15 & 15 & 15 \\
Bungkil kedelai & 20 & 20 & 20,25 \\
Dedak halus & 14 & 15 & 15 \\
Molasses & 10 & 9 & 8,5 \\
Garam & 0,5 & - & - \\
Mineral mix & 0,5 & - & - \\
$\mathrm{NH} 4 \mathrm{Cl}$ & - & 0,5 & - \\
$\left(\mathrm{NH}_{4}\right)_{3} \mathrm{PO}_{4}$ & - & 0,5 & - \\
$\mathrm{Na}_{2} \mathrm{CO}_{3}$ & - & - & 0,5 \\
$\mathrm{CaCO}_{3}$ & - & - & 0,75 \\
\hline
\end{tabular}

\section{Metode Penelitian}

Rancangan penelitian yang digunakan adalah rancangan acak kelompok (RAK) dengan 3 perlakuan dan 3 kelompok. Pengelompokan dilakukan berdasarkan bobot badan kelinci yang ditimbang diawal penelitian.

Tiga perlakuan yang digunakan yaitu :

T0 = Ransum kontrol, tanpa suplementasi mineral

$\mathrm{T} 1=$ Suplementasi mineral $\mathrm{NH}_{4} \mathrm{Cl} \quad 0,5 \%$ dan $\left(\mathrm{NH}_{4}\right)_{3} \mathrm{PO}_{4} \quad 0,37 \%$ pada ransum

$\mathrm{T} 2=$ Suplementasi mineral $\mathrm{Na}_{2} \mathrm{CO}_{3} 0,5 \%$ dan $\mathrm{CaCO}_{3} 0,45 \%$ pada ransum

Tiga kelompok yang digunakan yaitu :

Kelompok I $=$ BB Kelinci : $1,45 \pm 0,20 \mathrm{~kg}$

Kelompok II $=$ BB Kelinci : $2,51 \pm 0,21 \mathrm{~kg}$

Kelompok III $=$ BB Kelinci : 3,63 $\pm 0,33 \mathrm{~kg}$

Menurut Sastrosupadi (2000) metode linier percobaan yang digunakan adalah:

$$
\mathbf{Y i j}=\boldsymbol{\mu}+\mathbf{T i}+\boldsymbol{\beta} \mathbf{j}+\sum \mathbf{i j}
$$

Keterangan :

$\mathrm{i} \quad=1,2, \ldots \mathrm{t}$ (perlakuan).

$\mathrm{j}=1,2, \ldots \mathrm{r}$ (kelompok).

Yij = nilai pengamatan pada perlakuan ke-i kelompok ke-j.

$\mu=$ nilai tengah umum.

$\mathrm{Ti}=$ pengaruh perlakuan ke-i.

$\mathrm{Bij}=$ pengaruh kelompok ke-j.

$\sum \mathrm{ij}=$ pengaruh galat percobaan dari perlakuan ke-i dan kelompok ke-j.

\section{Parameter Penelitian}

1. Litter size (ekor / kelahiran)

Litter size merupakan jumlah anak sekelahiran dari seekor induk kelinci. 
2. Bobot lahir (gram / ekor)

Bobot lahir adalah berat anak saat lahir diperoleh dari rata-rata bobot lahir dari setiap induk.

3. Perbandingan anak jantan dan betina (ekor / litter size)

Perbandingan anak jantan dan betina di peroleh dari menghitung jumlah anak jantan dan anak betina dari setiap induk dalam satu kelahiran.

\section{HASIL DAN PEMBAHASAN}

\section{Uji pH Ransum dan pH Urin}

Uji $\mathrm{pH}$ terhadap ransum dan urin dilakukan sebelum pakan berupa pellet diberikan. Uji tersebut dilakukan dengan menggunakan kertas $\mathrm{pH}$ dan aquadest, diperoleh hasil bahwa pH ransum pada perlakuan T0 adalah 6, T1 adalah 5 dan T2 adalah 7. Uji pH ransum dan urin dilakukan untuk mengasumsikan $\mathrm{pH}$ tubuh yang terbentuk setelah mengkonsumsi ransum. Hasil uji pH ransum dan urin dapat dilihat pada Tabel 3.

Tabel 3. Hasil uji pH ransum dan $\mathrm{pH}$ urin pada induk kelinci

\begin{tabular}{ccc}
\hline \multirow{2}{*}{ Perlakuan } & \multicolumn{2}{c}{$\mathrm{pH}$ rata-rata } \\
\cline { 2 - 3 } & Ransum & Urin \\
\hline T0 & 6 & 8 \\
T1 & 5 & 8 \\
T2 & 7 & 8 \\
\hline
\end{tabular}

Ransum pada perlakuan T0 mengandung mineral yang umum digunakan yaitu mineral mix dan mineral lain yang terkandung didalam bahan pakan. Ransum ini merupakan ransum kontrol dengan $\mathrm{pH}$ 6. Ransum pada perlakuan T1 disuplemen dengan mineral P dan $\mathrm{Cl}$ dalam bentuk senyawa $\left(\mathrm{NH}_{4} \mathrm{Cl}\right.$ dan $\left.\left(\mathrm{NH}_{4}\right)_{3} \mathrm{PO}_{4}\right)$. Kondisi ransum yang asam dengan $\mathrm{pH} 5$ kemudian akan dikonsumsi oleh kelinci, diserap dalam saluran pencernaan, dan oleh darah dialirkan kesaluran reproduksi. Sehingga saluran reproduksi memiliki kondisi $\mathrm{pH}$ yang sejalan dengan $\mathrm{pH}$ ransum. Selanjutnya saluran reproduksi yang asam akan mempengaruhi proses embrionik, khususnya fertilisasi.

Ransum pada perlakuan T2 disuplemen dengan mineral $\mathrm{Na}$ dan $\mathrm{Ca}$ dalam bentuk senyawa $\left(\mathrm{Na}_{2} \mathrm{CO}_{3}\right.$ dan $\left.\mathrm{CaCO}_{3}\right)$. Proses penyerapan mineral ini dalam tubuh sama dengan penyerapan mineral $\mathrm{P}$ dan $\mathrm{Cl}$. Setelah dilakukan adaptasi pemberian pakan pada kelinci selama 2 minggu, dilakukan pengukuran pada $\mathrm{pH}$ urin, hasilnya semua urin kelinci bersifat basa dengan nilai $\mathrm{pH}$ rata-rata 8 , sedangkan $\mathrm{pH}$ ransum yang dikonsumsi bervariasi dengan 
selisih yang kecil yaitu 6, 5 dan 7. $\mathrm{pH}$ urin yang secara keseluruhan bersifat basa menunjukkan bila ternak kelinci masih mampu beradaptasi dengan baik dengan ransum yang memiliki pH antara 5 sampai 7. Hal itu terjadi karena didalam tubuh kelinci mineral yang disuplementasikan bereaksi sesuai dengan kemampuan adaptasi internal tubuh kelinci. Seperti dijelaskan Isnaeni (2006) bila setiap sistem hidup selalu bereaksi terhadap perubahan yang terjadi pada lingkungannya, mengatur dan mengontrol reaksi yang ditimbulkan, proses ini disebut dengan homeostasis. Disisi lain, kelinci termasuk hewan pemakan tumbuhan atau herbivora. Harjana (2008) menjelaskan bila umumnya $\mathrm{pH}$ urin hewan herbivora bersifat basa.

\section{Rekapitulasi Hasil Penelitian}

Data rekapitulasi hasil penelitian disajikan pada Tabel 4.

Tabel 4. Rekapitulasi pengaruh suplementasi mineral esensial dalam ransum terhadap Litter size, bobot lahir dan perbandingan anak jantan dan betina pada kelinci

\begin{tabular}{ccccc}
\hline Perlakuan & $\begin{array}{c}\text { Litter size } \\
\text { (ekor/kelahiran) }\end{array}$ & $\begin{array}{c}\text { Bobot lahir } \\
\text { (gram/ekor) }\end{array}$ & \multicolumn{2}{c}{ Perbandingan Anak Jantan dan Betina } \\
\cline { 3 - 5 } & & $\begin{array}{c}\text { Anak jantan } \\
\text { (ekor/litter size) }\end{array}$ & $\begin{array}{c}\text { Anak betina } \\
\text { (ekor / litter size) }\end{array}$ \\
\hline T0 & $6,22^{\text {tn }} \pm 1,17$ & $53,73^{\text {tn }} \pm 8,35$ & $3,44^{\text {tn }} \pm 1,02$ & $1,56^{\text {tn }} \pm 0,96$ \\
T1 & $6,89^{\text {tn }} \pm 0,38$ & $55,05^{\text {tn }} \pm 2,08$ & $1,89^{\text {tn }} \pm 0,38$ & $3,89^{\text {tn }} \pm 0,96$ \\
T2 & $5,89^{\text {tn }} \pm 0,84$ & $54,6^{\text {tn }} \pm 3,84$ & $2,11^{\text {tn }} \pm 0,51$ & $3,11^{\text {tn }} \pm 0,96$ \\
\hline
\end{tabular}

keterangan $: \mathrm{tn}=$ tidak berbeda nyata $(\mathrm{P}>0,05)$

\section{Litter size (jumlah anak sekelahiran)}

Litter size adalah jumlah anak sekelahiran dari seekor induk kelinci. Berdasarkan pada Tabel rekapitulasi, Rataan litter size tertinggi adalah pada perlakuan T1 dengan jumlah anak yang dilahirkan rata-rata 6,89 atau 7 ekor anak per induk.

Hasil analisis ragam dari data jumlah anak yang dilahirkan masing-masing induk pada setiap perlakuan maupun kelompok adalah tidak berbeda nyata $(\mathrm{P}>0,05)$. Artinya suplementasi mineral pembentuk suasana asam maupun basa pada ransum induk kelinci menunjukkan bila jumlah anak yang dihasilkan tidak berbeda dibandingkan pakan kontrol (T0).

Jumlah anak perkelahiran ditentukan oleh banyaknya spermatozoa yang berhasil melakukan fertilisasi dengan sel telur dalam ampula. Motilitas sperma itu sendiri di dalam saluran reproduksi betina sangat dipengaruhi oleh kondisi internal saluran reproduksi betina, yaitu media yang dilalui hingga sampai ketempat fertilisasi, bergantung pada $\mathrm{pH}$ dan suhu didalamnya.

Saluran reproduksi yang asam akan menghambat motilitas spermatozoa, sehingga kemungkinan untuk berhasil melakukan fertilisasi juga sedikit (Woo et. al, 2000). Oleh 
karena itu, jika dilihat dari $\mathrm{pH}$ ransum yang diberikan hanya berbeda satu angka (Tabel 3), belum mempengaruhi $\mathrm{pH}$ internal saluran reproduksi. $\mathrm{pH}$ ransum $\mathrm{T} 1$ adalah 5 , dan induk masih mampu menghasilkan anak dalam jumlah yang tidak berbeda dengan perlakuan T1 dan T2. Hal itu mengindikasikan jika adaptasi internal tubuh kelinci dalam mempertahankan asam-basa tubuhnya cukup baik pada tingkat $\mathrm{pH} 5$ yang cenderung asam, proses adaptasi ini disebut homeostasis (Isnaeni, 2006).

Melihat rata-rata induk kelinci menghasilkan anak 6 sampai 7 ekor dapat dinilai baik karena menurut Sarwono (2002) dan Manshur (2009) rata-rata induk kelinci melahirkan anak 6-8 ekor per litter size. Angka yang dinilai cukup baik itu mengindikasikan jika suplementasi mineral baik yang bersifat asam maupun basa tidak mengganggu kondisi internal saluran reproduksi betina pada saat proses fertilisasi yang pada intinya, kelinci masih mampu menghasilkan anak dalam jumlah yang normal.

\section{Bobot Lahir}

Bobot lahir kelinci adalah berat anak kelinci saat lahir, diperoleh dari rata-rata bobot lahir anak pada setiap kelahiran dari masing-masing induk kelinci. Hasil analisis ragam dari rataan bobot lahir anak kelinci menunjukkan hasil yang tidak berbeda nyata $(\mathrm{P}>0,05)$.

Rataan bobot lahir tertinggi adalah pada perlakuan T1 yaitu 55,5 g/ekor. Angka yang diperoleh itu masih dalam kategori normal, karena variasi bobot lahir pada kelinci adalah 2590 g/ekor (Karim, 2000), sementara untuk kelinci lokal sendiri dengan pemeliharaan intensif rata-rata adalah $49 \mathrm{~g}$ /ekor (Gofur, 1996).

Hal-hal yang mempengaruhi keragaman bobot lahir diantaranya adalah jumlah anak per litter size, faktor genetik dan lingkungan (Sumoprastowo, 1993 disitasi Sembiring, 2008). Umumnya semakin banyak anak dalam setiap kelahiran, bobot lahir akan semakin rendah (karim, 2000). Faktor lain yang mempengaruhi adalah konsumsi yang sangat fluktuatif bergantung pada lingkungan.

\section{Perbandingan Jenis Kelamin Anak Kelinci}

\section{Anak Jantan}

Jumlah anak jantan yang diperoleh selama penelitian bervariasi antara 1 sampai 5 ekor/litter size. Jenis kelamin anak yang dilahirkan ditentukan pada saat fertilisasi (Berry dan cromie, 2007) yang sangat bergantung pada nutrisi yang dikonsumsi induk sejak sebelum perkawinan (Prasojo et. al., 2010). Pada seluruh betina normal akan membawa kromosom X, 
sedangkan 50\% spermatozoa membawa kromosom $\mathrm{X}$ dan 50\% nya lagi membawa kromosom Y, sehingga secara teoritis $50 \%$ zigot hendaknya betina dan sisanya jantan.

Perlakuan terhadap pakan yang merupakan regulasi nutrisi berasumsi bahwa jika kelinci mengkonsumsi ransum yang mengandung mineral bersifat basa akan membuat spermatozoa berkromosom $\mathrm{Y}$ lebih aktif dibanding dengan spermatozoa berkromosom $\mathrm{X}$, sehingga lebih banyak yang berhasil melakukan fertilisasi di ampula kelinci betina dan lebih banyak terbentuk zigot jantan (berkromosom XY).

Hasil analisis ragam menunjukkan bila perlakuan pakan T0, T1 dan T2 serta pengelompokan berdasarkan bobot badan memberikan hasil yang tidak berbeda nyata $(\mathrm{P}>0,05)$ terhadap jumlah anak jantan. Hal ini mengindikasikan bila $\mathrm{pH}$ saluran reproduksi belum terbentuk sebagaimana yang diharapkan, sehingga anak jantan yang dihasilkan belum terlihat banyak secara signifikan.

\section{Anak Betina}

Jumlah anak betina yang dihasilkan masing-masing induk kelinci selama penelitian bervariasi antara1 sampai 6. Variasi yang diperoleh sedikit lebih banyak jika dibanding dengan jumlah anak jantan. Hasil analisis ragam pengaruh perlakuan terhadap jumlah anak betina menunjukkan bila $\mathrm{F}$ hitung lebih kecil dari perolehan $\mathrm{F}$ tabel, artinya jumlah anak betina yang dihasilkan tidak berbeda nyata $(\mathrm{P}>0,05)$.

Berdasarkan kecenderungan jumlah rataan anak betina yang lebih tinggi pada perlakuan pakan $\mathrm{T} 1$ (Tabel 4) mengindikasikan jika mineral $\mathrm{P}$ dan $\mathrm{Cl}$ mampu mempengaruhi kondisi internal saluran reproduksi betina, sehingga strategis untuk fertilisasi zigot betina. Hal itu didukung oleh pernyataan Harris dan Beed (1993) yang menyatakan jika penambahan unsur-unsur anion misalnya $\mathrm{Cl}^{-}$dan $\mathrm{P}^{=}$kedalam ransum akan menurunkan $\mathrm{pH}$ tubuh. Sementara Budinurdjaja (2007) dan Fathul et al. (2008) menjelaskan bila spermatozoa yang membawa kromosom $\mathrm{X}$ lebih tahan pada kondisi $\mathrm{pH}$ yang rendah, sehingga lebih aktif dibandingkan spermatozoa berkromosom Y dalam hal melakukan fertilisasi di ampula tuba falopii. Spermatozoa berkromosom X melakukan fertilisasi dengan sel telur (X) dan akan menghasilkan anak betina (XX).

Perbandingan anak jantan dan betina dianalisis dari jumlah masing-masing jenis kelamin anak dari setiap induk kelinci. Jika dilihat dari perbandingan kelamin anak yang dihasilkan dengan pemberian pakan yang mengandung mineral bersifat asam maupun basa, perbandingan yang diperoleh dapat dilihat pada Tabel 5. 
Tabel 5. Perbandingan anak jantan dan betina

\begin{tabular}{cccc}
\hline Perlakuan & $\begin{array}{c}\text { Anak jantan } \\
\text { (ekor/litter size) }\end{array}$ & $\begin{array}{c}\text { Anak betina } \\
\text { (ekor/litter size) }\end{array}$ & Perbandingan \\
\hline T0 & 3,44 & 1,56 & 2,20 \\
T1 & 1,89 & 3,89 & 2,05 \\
T2 & 2,11 & 3,11 & 1,47 \\
\hline
\end{tabular}

Berdasarkan Tabel 5, perbandingan jumlah anak jantan dan betina pada perlakuan pakan T0 (tanpa suplementasi mineral) adalah 2,20. Artinya, jumlah anak jantan yang dihasilkan adalah 2,20 kali lebih banyak dibandingkan jumlah anak betina. Perbandingan jumlah anak jantan dan betina pada perlakuan pakan T1 (suplementasi mineral bersifat asam) adalah 2,05. Artinya, jumlah anak jantan yang dihasilkan 2,05 kali lebih sedikit dari jumlah anak betina atau, jumlah anak betina 2,05 kali lebih banyak dibanding anak jantan. Pada perlakuan ini perbandingan anak betina lebih tinggi dibanding anak jantan.

Angka perbandingan anak jantan dan betina pada perlakuan pakan T2 (suplementasi mineral bersifat basa) adalah 1,47. Artinya, jumlah anak jantan yang dihasilkan 1,47 kali lebih sedikit dari jumlah anak betina. Sebaliknya, perlakuan ini menghasilkan anak betina 1,47 kali lebih banyak dibanding anak jantan.

\section{KESIMPULAN}

Suplementasi mineral $\mathrm{Na}(0,5 \%), \mathrm{Ca}(0,45 \%), \mathrm{P}(0,37 \%)$ dan $\mathrm{Cl} \quad(0,5 \%)$ dalam ransum kelinci belum mampu meningkatkan jumlah anak jantan dan betina per litter size, namun sudah terjadi kecenderungan peningkatan jumlah anak betina pada kondisi asam (pakan mengandung mineral $\mathrm{P}$ dan $\mathrm{Cl}$ ).

\section{DAFTAR PUSTAKA}

Brahmantiyo, B. 2007. Budi Daya Kelinci. Balai Penelitian Ternak. Ciawi, Bogor.

Budinurdjaja, P. 2007. Kiat Mendapatkan Bayi Normal: Menjawab Masalah Seputar Kehamilan. Edisi pertama. Penerbit Pustaka Banua, Banjarmasin Kalimantan Selatan.

Fathul F. et al., 2008. Keasaman Cairan Tubuh dan Ratio Kelamin Anak Domba Garut (Ovis aries) yang Diberi Kation-Anion Ransum yang Berbeda. Skripsi.Institut Pertanian Bogor, Bogor.

Gofur. 1996. Super Ovulasi Kelinci Lokal. CHIMERA, ISSN 0853-8824 th 1 no 2.

Harjana, T., 2008. Struktur dan Fungsi Hewan (sistem ekskresi). Universitas Negri Yogyakarta, Yogyakarta. 
Harris Jr. B, Beed D.K. 1993. Dietary cation-anion balancing of rations in the prepartum or late dry period. Seri of the animal science Departement Florida Cooperative extension service. University of Florida.

Isnaeni W., 2006. Fisiologi Hewan. Kanisius. Yogyakarta.

Karim, L., 2000. Produktivitas Induk kelinci muda persilangan pada bobot hidup lebih dari dua kilogram. Skripsi. Institut Pertanian Bogor. Bogor.

Manshur F., 2009. Ternak Uang Bersama Kelinci: Menjadi Jutawan Sambil Menyalurkan Hobi. Nuansa, Bandung.

Prasojo G. et al., 2010. Korelasi Antara Lama Kebuntingan, Bobot lahir dan Jenis Kelamin Pedet Hasil Inseminasi Buatan pada Sapi Bali. Institut Pertanian Bogor, Bogor.

Sarwono., 2002. Kelinci Potong dan Hias. Agromedia. Jakarta.

Sembiring, D. L., 2008. Pengaruh Frekuensi Perkawinan dan Sex Ratio Terhadap Litter Size, Bobot Lahir, Mortalitas Selama Menyusui dan Bobot sapih pada kelinci Persilangan. Skripsi.Universitas Sumatera Utara, Medan.

Sinaga J. R., 2009. Pengujian Suplementasi Mineral Esensial (Ca, P, Na dan $\mathrm{Cl}$ ) dalam Ransum Terhadap Fertilitas, Daya Tetas dan Mortalitas Pada Telur Burung Puyuh (Coturnix-Coturnix Japonica). Skripsi. Universitas Sumatera Utara, Medan.

Woo, A.L., P.F. James \& J.B. Lingrei. 2000. Sperm motility is dependent on a unique isoform of Na,K-ATPase. J. Biol. Chem. 275:20693-2069 